\title{
Blood transfusion requirements and filter longevity with regional citrate anticoagulation compared with heparin
}

\author{
E Burford, E Walter, A Beverly* \\ From ESICM LIVES 2015 \\ Berlin, Germany. 3-7 October 2015
}

\begin{abstract}
Introduction
Citrate is the recommended anticoagulant for continuous renal replacement therapy (RRT) [1], and is thought to confer numerous benefits, including more continuous hours of filtration, fewer total circuits used, less overall cost and maybe improved patient and kidney survival when compared with heparin anticoagulation [2]. Our ICU changed from heparin to citrate anticoagulation in June 2014. Our unit uses a transfusion trigger of $7 \mathrm{~g} / \mathrm{dl}[3]$ unless the clinical situation dictates otherwise.
\end{abstract}

\section{Objectives}

This observational study is to investigate blood transfusion requirements and haemofilter set life before and after the change from systemic heparin to citrate regional anticoagulation, to add to growing international evidence, and to inform local practice.

\section{Methods}

Data were collected on set life and the number of blood transfusions patients received during the period of filtration, and in the 24 hours afterwards. Data on patients anticoagulated with heparin were collected retrospectively up until the day of changing to citrate. Data during citrate anticoagulation were collected prospectively, from the day of changing, onwards.

\section{Results}

6 months of filtration with heparin and 3 months of citrate were observed. 97 patients required RRT (65 with heparin, 28 with citrate, 4 with both), for a total of 556 days. Table one shows the comparison between

Royal Surrey County Hospital, Intensive Care Unit, Guildford, United Kingdom
Table 1 Comparison of citrate with heparin anticoagulation.

\begin{tabular}{lll}
\hline & Heparin & Citrate \\
\hline Renal days & 357 & 199 \\
\hline Median renal days per patient episode & 3 & 3 \\
\hline Number of filters used & 408 & 128 \\
\hline Total filter cost $(\cdot)$ & 32807.28 & 10292.48 \\
\hline Renal days per filter & 0.86 & 1.55 \\
\hline Filter cost per renal day $(\cdot)$ & 91.89 & 51.72 \\
\hline Blood transfusions per day & 0.33 & 0.25 \\
\hline
\end{tabular}

heparin and citrate. There was no difference in the average duration of filtration required between the 2 systems. Filter life increased from 0.86 days with heparin, to 1.55 days with citrate ( $\mathrm{p}=0.007$ by Student $\mathrm{t}$-test). The number of transfusions required fell from 0.33 units per day with heparin, to 0.25 units per day with citrate $(\mathrm{p}>0.05)$.

\section{Conclusions}

Regional citrate anticoagulation increases filter life when compared with systemic heparinisation, with significant cost and other savings. There is a non-significant trend towards a reduction in blood transfusion requirements.

Published: 1 October 2015

\section{References}

1. Kidney Disease: Improving Global Outcomes (KDIGO) Acute Kidney Injury Work Group. Kidney inter., Suppl 2012, 2:1-138, KDIGO Clinical Practice Guideline for Acute Kidney Injury.

2. Oudemans-van Straaten HM, Kellum JA, Bellomo R: Clinical review: Anticoagulation for continuous renal replacement therapy - heparin or citrate? Crit Care 2010, 15(1):202. 
3. Hébert PC, Wells G, Blajchman MA, Marshall J, Martin C, Pagliarello G, et al A Multicenter, Randomized, Controlled Clinical Trial of Transfusion Requirements in Critical Care. N Engl J Med 1999, 340(6):409-417.

doi:10.1186/2197-425X-3-S1-A462

Cite this article as: Burford et al: Blood transfusion requirements and filter longevity with regional citrate anticoagulation compared with heparin. Intensive Care Medicine Experimental 2015 3(Suppl 1):A462.

\section{Submit your manuscript to a SpringerOpen ${ }^{\mathcal{O}}$ journal and benefit from:}

- Convenient online submission

- Rigorous peer review

- Immediate publication on acceptance

- Open access: articles freely available online

- High visibility within the field

- Retaining the copyright to your article

Submit your next manuscript at $\gg$ springeropen.com 